\title{
Digitalization and A.I. as Challenges and Chances for Future Teaching and Teacher Education: A Reflection
}

\author{
Horst Zeinz \\ Faculty of Educational and Social Sciences, University of Muenster, \\ Germany \\ horst.zeinz@uni-muenster.de
}

\begin{abstract}
Digitalization as a key issue of society is increasingly a topic in school. Authorities like the recently deceased scientist Stephen Hawking and the founder and CEO of Tesla, Elon Musk, see both challenges and chances in the developing artificial intelligence (A.I.). Musk remarked: "A.I. will be the best or worst thing ever for humanity" (CNBC 1 2017). The solution, Musk said, is to increase regulatory oversight of the development and implementation of A.I. immediately: "AI is a rare case where I think we need to be proactive in regulation than be reactive." (CNBC 2 2017). Stephen Hawking emphasizes the same point: "The emergence of A.I. could be the "worst event in the history of our civilization" unless society finds a way to control its development (...). Success in creating effective A.I. could be the biggest event in the history of our civilization. Or the worst. We just don't know." Hawking said during a talk at the Web Summit technology conference in Lisbon, Portugal, in 2017. (CNBC 3 2017). In view of these considerations and in regard to the meaning for education in school the question arises: Which topics and competencies should be presented to pupils against the background of the rapid processing in the field of digitalization and the corresponding uncertainty of topics and competencies that could be of importance in some years and decades? Verbalized differently: What does sustainable education for our future include? The answer will be aimed at the teaching and acquirement of basic competencies in general and in the field of digitalization. What should this "basic education" include? Another question is: How is it possible to combine learning processes in a "virtual reality" with learning processes in a "natural reality"? Further considerations are given in this article.
\end{abstract}




\section{Keywords}

digitalization - artificial intelligence - teaching - teacher education

Regarding the use of cell phones and other devices that allow us to be "connected" via the internet, Dylan Curran, a data consultant and web developer, who does extensive research into spreading technical awareness and improving digital etiquette, writes: "This is one of the craziest things about the modern age. We would never let the government or a corporation put cameras/ microphones in our homes or location trackers on us. But we just went ahead and did it ourselves because - to hell with it! - I want to watch cute dog videos." (Curran 2018).

In fact, our "digital reality" seems to be pretty close to possibilities that were described in George Orwell's 1984: “Google knows where you've been. Google stores your location (if you have location tracking turned on) every time you turn on your phone. You can see a timeline of where you've been from the very first day you started using Google on your phone. (...). Google knows everything you've ever searched - and deleted. Google stores search history across all your devices. That can mean that, even if you delete your search history and phone history on one device, it may still have data saved from other devices. (...).Google has an advertisement profile of you. Google creates an advertisement profile based on your information, including your location, gender, age, hobbies, career, interests, relationship status, possible weight (need to lose 1olb in one day?) and income. (...). Google knows all the apps you use. Google stores information on every app and extension you use. They know how often you use them, where you use them, and who you use them to interact with. That means they know who you talk to on Facebook, what countries are you speaking with, what time you go to sleep. (...). Google has all of your YouTube history. Google stores all of your YouTube history, so they probably know whether you're going to be a parent soon, if you're a conservative, if you're a progressive, if you're Jewish, Christian, or Muslim, if you're feeling depressed or suicidal, if you're anorexic ...The data Google has on you can fill millions of Word documents (...). Facebook stores everything from your stickers to your login location (...). They can access your webcam and microphone. The data they collect includes tracking where you are, what applications you have installed, when you use them, what you use them for, access to your webcam and microphone at any time, your contacts, your emails, your calendar, your call history, the messages you send and receive, the files you download, the games you play, your photos and videos, your music, your search history, your 
browsing history, even what radio stations you listen to. (...). Google knows which events you attended, and when (...). And Google has information you deleted (...). Google can know your workout routine (...).And they have years' worth of photos (...). Google has every email you ever sent (...). And there is more (...). First, every Google Ad I've ever viewed or clicked on, every app I've ever launched or used and when I did it, every website I've ever visited and what time I did it at, and every app I've ever installed or searched for. They also have every image I've ever searched for and saved, every location I've ever searched for or clicked on, every news article I've ever searched for or read, and every single Google search I've made since 2009. And then finally, every YouTube video I've ever searched for or viewed, since 2008." (Curran 2018).

The author writes about his investigations regarding his own data at the search engine/social media he uses. Of course: Other internet tools might not work much differently. This seems to be one of the big changes and challenges in our society: We become more and more "transparent" as the data that we create are used by others in many ways, often in order to sell us something. Questions arise like: Who has a profit of us "being connected"? or: Which are the fields that should not be connected (security and privacy vs. control and surveillance)?

\section{A.I. as a Part of Our Future}

Another big change and challenge is the developing artificial intelligence. Science fiction movies like "I, Robot" tell stories of a future in which mankind has to fight in order to stay alive against machines that once were created by humans. Could this scenario become real one day? Some of the leading authorities in our society seem not to be sure about this question: "Elon Musk has become a de facto leading voice about the potential of robotics and artificial, machine learning - and he has issued both cool predictions and scary ones. (...) Robots will move so fast you need a strobe light to see them. (...) "AI will be the best or worst thing ever for humanity," says the billionaire entrepreneur." (CNBC 1, 2017).

"Elon Musk is certain that robots will be able to do your job better than you. And even the billionaire CEO of Tesla and SpaceX is not sure what to do about that. "There certainly will be job disruption. Because what's going to happen is robots will be able to do everything better than us. ... I mean all of us," says Musk, speaking to the National Governors Association (...). If robots take your job, the government might have to pay you to live." (CNBC 2, 2017). 
"AI is a fundamental risk to the existence of human civilization in a way that car accidents, airplane crashes, faulty drugs or bad food were not - they were harmful to a set of individuals within society, of course, but they were not harmful to society as a whole." According to Musk, the solution is to increase regulatory oversight of the development and implementation of artificial intelligence as soon as possible. "AI is a rare case where I think we need to be proactive in regulation than be reactive," he says. (CNBC 2, 2017).

"Elon Musk said (...) that artificial intelligence could be the 'most likely' cause of a third world war. (...) Musk said that there was a possibility that war could be automated. In response to one Twitter user, he said: 'May be initiated not by the country leaders, but one of the AI's if it decides that a prepemtive (sic) strike is the most probable path to victory"'. (CNBC 4, 2017).

So one further question is: Can A.I. become dangerous for the survival of mankind? The recently deceased scientist Stephen Hawking said: "The emergence of artificial intelligence (AI) could be the 'worst event in the history of our civilization' unless society finds a way to control its development (...). 'Success in creating effective AI, could be the biggest event in the history of our civilization. Or the worst. We just don't know. So we cannot know if we will be infinitely helped by AI, or ignored by it and side-lined, or conceivably destroyed by it,' Hawking said during the speech." (Web Summit technology conference in Lisbon, Portugal, 2017). "Unless we learn how to prepare for, and avoid, the potential risks, AI could be the worst event in the history of our civilization. It brings dangers, like powerful autonomous weapons, or new ways for the few to oppress the many. It could bring great disruption to our economy." (CNBC 3, 2017).

"Hawking explained that to avoid this potential reality, creators of AI need to 'employ best practice and effective management.' The scientist highlighted some of the legislative work being carried out in Europe, particularly proposals put forward by lawmakers earlier this year to establish new rules around AI and robotics. Members of the European Parliament said European Unionwide rules were needed on the matter. Such developments are giving Hawking hope. 'I am an optimist and I believe that we can create AI for the good of the world. That it can work in harmony with us. We simply need to be aware of the dangers, identify them, employ the best possible practice and management, and prepare for its consequences well in advance,' Hawking said." (CNBC 3 , 2017).

Questions that arise regarding these thoughts could be: Can/should the development of A.I. include features/qualities like "emotional intelligence" (E.I.) or "humanity"? What are/should be qualities like E.I. or humanity? Who will be deciding? And who will be monitoring? In order to face these challenges: Do we need a more normative pedagogy/education in future? Do we have to care 
more about the advancement regarding values and socio-emotional competences (instead of just cognitive competences)?

\section{Fundamental Questions}

These thoughts bring us to another, very fundamental question: Who am I? (Or: What is a human being?) Above the entrance of the famous ancient oracle of Delphi was a sign that said (translated into English): "Recognize yourself!" We are not only able to think, but we are able to watch our thinking as an "observer". Therefore we are more than our thoughts, our memories, our emotions and our physical body. But what are we then? Either our body, our brain is the source of our awareness. Then this awareness passes with the dead of our physical body. Or: We are soul, an eternal being that incarnates and uses the body in order to make experiences in this world. Then the dead of the physical body would be no more than a chapter in the book of our experiences. Nevertheless: We are more than just our cognitions because we have feelings and emotions, and we have a physical body. All of these "parts" of a human being need to be trained in one or the other way.

Following this "holistic view" the importance of a big variety of subjects in school becomes clear. Not only mathematics and our native language are important for our own development, but other subjects like art, music and sports, too.

What are the differences between a human being and robots then? Gregor Gysi, a well known German politician, said regarding this question that robots would not be able to do three things: to lead, to feel and to reproduce. (Gysi 2018). "Not yet" we might think. But: There is a fundamental difference between feeling something and imitating a reaction of a feeling.

Ebert (2016) writes about some interesting aspects that can (in his opinion) identify human beings: We all would have a certain amount of irrationality in common. As human beings we would be living paradoxes. Sometimes there would be light years between knowing and acting. Our brain would not calculate but simply would like to feel good. This would lead to the addiction to alcohol, to the listening to music and to financial crises. If our brain would (only) calculate, it would just follow the laws of nature and the laws of mathematics, and we would be no more than a machine, without feelings, without temptations, without cognitive dissonances, faith and self-deception. We would (only) work. But there would be no space for crazy ideas, for illusions and for something (really) new. Ebert (2016) further writes that our irrationality would be the secret of our creativity and of our fantasy. It would be our unreasonableness that insists not on us adapting to the world, but on the world that should adapt on us. 
Therefore any kind of progress would highly depend on our irrationality. And he cites Ludwig Wittgenstein who formulated that no reasonable thing would happen if people would never do something stupid (Ebert 2016, 232-233).

All of these considerations bring us to the question of the role that digitalization and its future development play for education in school. But first of all: What do pupils already know regarding the use of a personal computer, a cell phone and the internet?

As an example representative data from German children (age six to thirteen) are reported next. Among the "internet activities" of these children the most frequent answers in 2016 were: "using search engines", "sending messages via WhatsApp" and "watching YouTube-videos" (MPFS 2016). This is the result of a study called "КІм" that is done by the "Medienpädagogischen Forschungsverbund Südwest (mpfs)" on a regular basis in all regions of Germany. Besides the aspect of entertainment there are two fields addressed that are of a great importance of the pupils' work at the PC as well (apart from the use of specific learning programs): communication (e.g. email-contacts with pupils from other regions of the world) and information search. In this article we focus on information search with the help of the project "Building Bridges". Main task of the project is the combination of digitalization and learning by doing. So one important part of education is and will be to teach both: to live and learn in a virtual world and to live and learn in a natural world.

What does sustainable education for our future include?

What should a basic education regarding digitalization include?

The answer that is given with respect to primary school education (e.g. Einsiedler 2014) would be aimed at the communication and the acquirement of basic competencies in general and in the field of digitalization. Important examples for challenges that are typical in a certain era (Klafki 1985) as a part of basic education are for example peace education, environmental education and education regarding media.

Each person is both an individual and part of a class and a school community, which again is part of our society and of the pool of all societies in this world. The area of conflict between a human as a self-determined and unique being on the one hand and as a social being with responsibility for oneself, for others and for the environment (e.g. Zeinz 2009) on the other hand is meaningful for processes of global learning. 
Global learning aims for sustainable development, for learning to take other perspectives and for learning empathy as well as to evolve our own identities. It aims to achieve the ability to take responsible actions and decisions (Scheunpflug 2017). Global education is an umbrella term, coined to bring together a variety of contents like human rights education, development education, environmental education, peace education, and so on. Two connected contents of global learning that are mentioned next are peace education and education regarding media.

\section{Peace Education}

Peace education starts with thoughts, virtues and attitudes. At the beginning of the constitution of the United Nations Educational, Scientific and Cultural Organization (UNESCO) that was signed on 16 November 1945 by twenty countries you can read: "The governments of the states parties to this constitution on behalf of their peoples declare: That since wars begin in the minds of men, it is in the minds of men that the defences of peace must be constructed." (UNESCO 1945). What a great sentence! How can we construct the defences of peace in times of global learning? Here I mainly follow the thoughts of the author Uli Jäger that were published by the Federal Agency for Civic Education of Germany.

In numerous model projects best-practice-examples as a form of learning by observation have been established in peace education. Empowerment has become a fundamental part of peace education in regions of conflict and war. The nonviolent resistance to poverty, rejection, marginalization, violence and war takes courage, firmness and self-confidence. The basic methodological approach of peace education is to create room for self-reflection and for learning together, for encounter and for critical discussions. Peace education often is regarded as a holistic approach: It is appropriate that there is a connection between the individual level, the social level and the international level as well as of the fields of formal and non-formal education, and all the representatives involved. Therefore it is called "multi-track-peace education". (Jäger 2015).

Schools are not automatically places of peace education. They also can be places of personal, structural or cultural violence and they can even directly incite violence and therefore they can contribute to a worsening and a hardening of ethnic, religious and social tensions, conflicts and discriminations.

School books can harden conflicts by passing on unilateral descriptions of conflicts to new generations of students again and again. This was shown by 
research of the Georg-Eckert-Institut für Internationale Schulbuchforschung that's an institute for international school book research in Braunschweig, Germany. They are doing research on the impact of social conflicts in school books as well as on avoiding the violent escalation of conflicts and on supporting a constructive development by suitable learning opportunities.

In the "Education for All Global Monitoring Report" of UnEsco (United Nations Educational, Scientific and Cultural Organization) from 2010 you can read that armed conflicts are often connected with dissatisfaction and perceived inequities that have to do with identity, belief, ethnicity and religion." In all of these fields education can make the difference by turning the balance to peace or to conflict." (Jäger 2015).

Results of a study from Heidelberg, Germany show that the participation in projects of peace education has a positive effect on the peaceableness of the participants: They are more willing to approach members of other groups of a conflict and they have a greater belief in the success of civil conflict solving than people who have not participated in the projects of peace education. There is also evidence showing the impact of non-involved, neutral representatives for helpful motivation in situations when conflicts are stuck.

The United Nations Children's Fund (UNICEF) as a United Nations (UN) program explains that "education is not a marginal player in peacebuilding, but a core component of building sustainable peace." (UNICEF 2011).

An important step to enhance the impact of projects of peace education in the future is to train persons of influence in different areas of education and in the widest range of levels - from primary schools to the governing bodies who make educational policy. (Jäger 2016).

\section{Education Regarding Media}

In times of globalization, peace education is closely connected with education in the field of media. Competence in the field of media is a central objective of education. Related to conflicts and war this means the teaching about media, the review of media and the active arrangement of media. Contents of the teachings about media are for example:

... the question of where to find information,

... the knowledge of where and in which medium a conflict is reported (for example in print media, in TV, in the internet and so on), ... and the knowledge about certain genres with different approaches to the subject. (Jäger 2015). 
There are inequities regarding the access to the internet: Politically excluded ethnic parts of the population have less access to the internet than other parts of the population with political power within the same country. In democratic countries there are less excluded groups of population. Therefore digital inequity mainly is a problem in non-democratic countries. These are the results of a study that was conducted by the universities of Konstanz, Germany and Zürich, Switzerland in 2016 with data from more than 500 ethnic groups from 118 different countries. The authors of this study do not think that the inequities regarding the access to the internet can be eliminated by financial means alone. Rather important would be the support of the regional political players. (DHV 2016, 905).

The second area of education in the field of media is the review of media. Possible central questions for the review of media are: What do they show us - and what not? Who tells what and how do they tell it - and what is not reported? Which intentions are followed, for example by "embedded journalists"? Our images of war are even influenced by movies and computer games. A description of these "inner images" and a comparison with the likely proceedings on location would be of great value, too. Not only during war there are people who intentionally strive for manipulation, mainly in order to justify their suspicious deeds or in order to sell something to others.

The term "Post Truth" was elected as the "International Word of the Year" 2016. In the explanatory statement the society for the German language in Wiesbaden states that there would be a growing impact of emotions instead of facts in political and social discussions. In this respect the term would stand for a deep political change. More and more people from all the different classes of population would agree to ignore facts and even to accept obvious lies out of antipathy to the upper crust. (T-Online 2016). The term "Fake News" is nothing else but another euphemism for the word "lies".

Education can contribute to the revelation of the background of these contexts. It can bring more awareness to questions like:To which extent social media on the internet are reliable sources? One argument given by a person after being convicted of spreading lies is that news need to be as up-to-date as possible and that time is too short to investigate properly in the face of other competitors. Why should we believe any longer a source that has spread lies? What advantage do we have of fast news if they are lies? And what damage do these lies cause? These are questions that can be discussed during the review of media.

The last and most important area of education in the field of media is the active arrangement of media. That means the practical ability of each individual to handle media in an active way. This covers the knowledge about the possibilities to join discussion platforms on the internet (for example at the UNICEF youth network (unicef.org/magic)). and the use of video, photography, 
computer, and so on to articulate the personal point of view. An example for this is the project "theoneminutesJr." of UNICEF. (Götz 2005).

Wars arise in one's head. Education is able to interrupt the circuit, if it shows the effects of war and violence and if it creates room for learning together. It mainly has to do with the communication of a nonviolent handling of conflicts. (Jäger 2016).

\section{Nonviolent Communication}

The nonviolent communication that was introduced by Marshall Rosenberg is a good example of how to implement global education and peace education.

What does nonviolent communication mean?

I'll quote from the website of the Center for Nonviolent Communication here. That is an organization which was founded by Marshall Rosenberg. They first refer to the question: What is violent communication? If "violent" means acting in ways that result in hurt or harm, then much of how we communicate judging others, bullying, having racial bias, blaming, finger pointing, discriminating, speaking without listening, criticizing others or ourselves, name-calling, reacting when angry, using political rhetoric, being defensive or judging who's "good/bad" or what's "right/wrong" with people - could indeed be called "violent communication."

What is nonviolent communication? Nonviolent communication is the integration of different things:

- Consciousness: a set of principles that support living a life of empathy, care, courage, and authenticity

- Language: understanding how words contribute to connection or distance

- Communication: knowing how to ask for what we want, how to hear others even in disagreement, and how to move toward solutions that work for all

- Means of influence: sharing "power with others" rather than using "power over others" (Rosenberg 1).

"Nonviolent communication serves our desire to do three things:

1. Increase our ability to live with choice, meaning, and connection

2. Connect empathically with self and others to have more satisfying relationships

3. Sharing of resources so everyone is able to benefit" (Rosenberg 1.).

"Nonviolent communication contains nothing new. It is based on historical principles of nonviolence - the natural state of compassion when no violence 
is present in the heart. Nonviolent communication reminds us what we already instinctively know about how good it feels to authentically connect to another human being. With Nonviolent communication we learn to hear our own deeper needs and those of others. Through its emphasis on deep listening to ourselves as well as others - nonviolent communication helps us discover the depth of our own compassion. This language reveals the awareness that all human beings are only trying to honor universal values and needs, every minute, every day. Nonviolent communication can be seen as both a spiritual practice that helps us see our common humanity, using our power in a way that honors everyone's needs, and a concrete set of skills which help us create life-serving families and communities." (Rosenberg 2).

"Some people use nonviolent communication to create greater depth and caring in their intimate relationships. Others use it to build more effective relationships at work. Still others use this process in the political arena. Worldwide, Nonviolent communication now serves as a valuable resource for communities facing violent conflicts and severe ethnic, religious or political tensions." (Rosenberg 3).

In order to break these thoughts down for children, for example at the age of primary school students, there has been developed the concept of the giraffe language versus the jackal language.

This is how the giraffe language for children can be introduced: The giraffe has the biggest heart of all the mammals in the world. It needs such a big heart to pump its blood through the long neck into its head. The giraffe lives peacefully with different animals, with antilopes, zebras, lions and elephants. The giraffe has this long neck and watches the world from above. This is why it sees and observes things other animals cannot see. It does not take anything from other animals because with its long neck it feeds only on what other animals cannot reach. Therefore quarrels with the giraffes don't arise and it can live peacefully with all the other animals. This is why we borrow the name of the giraffe to identify a certain manner of how to talk to and treat each others. We try to speak of giraffe language, when people have a big heart, understand others well and if they talk to others in an open and friendly way. Giraffe language helps us when quarreling or being of different opinions.

Features of Giraffe Language

I tell the other what disturbs me without offending him. I speak out what I feel. I clearly tell what I wish. I formulate a request or a wish.

Now we come to the jackal language: 
Adults and children do not manage always to talk in giraffe language. Sometimes they are worried, furious and disappointed or they are frightened. This is when they use jackal language. Jackals represent beings who do not have the view of the giraffes and do not have such a big heart. When jackals are furious they snap, snarl at others and hurt them in some way. When jackals are frightened they hide their feelings and do not speak out how they feel. We will now identify a language as jackal language, which denotes fears, disappointment, fury and taciturnity.

Features of the jackal language: I hurt others with my words. I tell something bad about the others. I leave no options to others with my words. I speak full of fury and look for a reason to quarrel. (Rosenberg 2).

Marshall Rosenberg said: "Peace requires something far more difficult than revenge or merely turning the other cheek; it requires empathizing with the fears and unmet needs that provide the impetus for people to attack each other. Being aware of those feelings and needs, people lose their desires to attack back because they see the human ignorance leading to those attacks. Instead, their goal becomes providing the empathic connection and education that will enable them to transcend their violence and engage in cooperative relationships." (Rosenberg 4).

"I would like us to create peace at three levels and have each of us to know how to do it. First, within ourselves. That is to know how we can be peaceful with ourselves when we're less than perfect, for example. How we can learn from our limitations without blaming and punishing our self. If we can't do that, I'm not too optimistic how we're going to relate peacefully out in the world. Second, between people. Nonviolent communication training shows people how to create peace within themselves and at the same time how to create connections with other people that allows compassionate giving to take place naturally. And third, in our social systems. To look out at the structures that we've created, the governmental structures and other structures, and to look at whether they support peaceful connections between us and if not, to transform those structures." (Rosenberg 4).

On the website of the Center for Nonviolent Communication there is another quote I'd like to share with you in closing. It is from Rumi. It says: "Out beyond ideas of wrongdoing, and right-doing, there is a field. I will meet you there." (Rumi).

How is it possible to combine learning processes in a "virtual reality" with learning processes in a "natural reality"?

Each of us is able to contribute to a more peaceful world in his or her "little world" which is his or her sphere of influence. Education means to influence 
people in a positive way. What could be "positive" and who has the right to decide what is "positive"? Some hints to possible answers were given earlier in this text.

School is an important sphere of influence for children and for young adults. So: How is it possible to combine learning processes in a "virtual reality" with learning processes in a "natural reality" in school? As an example we next take a look at a project called "Building Bridges" that combines learning by doing and digital learning.

\section{$8 \quad$ Learning by Doing}

We can find the idea of learning by doing already in a lot of forms of reform pedagogy in the early 2oth century. The idea of learning by doing is repeatedly emphasized especially for primary schools (e.g. Bayerischer Grundschullehrplan 2014). Actual findings of brain research support this approach (e.g. Hüther 2015). "Movement supports blood circulation and metabolic processes and therefore builds an auxiliary climate for all neuroplastic processes that are connected with learning. As neuromuscular part of cognitive learning processes movement generally is part of every learning process. While we talk and do things during learning processes neuromuscular centers are automatically involved that lead to a better and more sustainable learning. (...). At the same time movement means more than just sports but neuromuscular activity in the broadest sense." (e.g. Gasse \& Dobbelstein 2008).

The project described next is an example that shows how the aspect of movement can be an important part of learning by doing in which pupils have the freedom to move inside the classroom.

The class $3 \mathrm{~b}$ of the Friedrich-Rückert-school in Erlangen, Germany, became a "tablet class" for four weeks during the school year 2017/18. During this time each child got an own tablet. There were two emphases in this project: At the beginning the use of the practice software that was on the device was in the foreground. Objectives were on the one hand the introduction of the tablet and the reliable handling with it, and on the other hand the adaptive exercises and the individualized practice. These adaptive forms of exercises were available for the subjects mathematics and German (as native language). Numerous tasks with the possibility of self-evaluation were provided. The teacher was able to check how many tasks were fulfilled, how many were 
solved correctly and when the work has been done. He used this function in order to give each child a certain amount of tasks individually. When the work was finished successfully further tasks could be distributed.

The second emphasis was the actual project "Building Bridges". Here the tablet fulfilled the meaning of information search. First the pupils learned of the conditions of stability of bridges via direct instruction in class. Especially the "bridge experiment" was impressive: The pupils stuck together wooden parts and tested the stability in connection with standing on the structure they had built. After that each child got the name of an existing bridge connected with the mission: Collect information, search suitable material, and build your bridge! The pupils could work on their own, or they were free to choose to work in pairs or in groups, depending on the problem statement and on the tasks. Sometimes a pupil first figured out things for him- or herself, then asked for some help and others joined him or her. Then the problem was solved in group work and then the group disbanded. It was an arrangement that the parents should not do the work for their kids and that the work on the project should only be done at school. The children could do experiments with different material and use it as needed. They used all kind of paper, different kind of wood, ropes, Lego- building stones and so on that were available in the classroom for this purpose. Additional there was a book with contents like "wanted poster of bridges", "typs of bridges" and "technical terms" (Bohnenkamp \& Luther 2015). Finally all together worked on a presentation for the parents that was shown at the school's summer fest. Here the children displayed their bridge models, designed posters, and presented their opinion to the project in written words. Each pupil created an individual bridge journal. Together they figured out a quiz. In order to answer it, the guests had to read the posters and to compare the existing bridges from all over the world. The children guided their parents along the exhibition, explained things and helped answering the quiz. The parents and relatives enjoyed the performance of the children and were able to convince themselves about the spectrum of this project.

Indeed the project "Building Bridges" was able to build several bridges. The main aspect is that it is an example of building a bridge between learning processes in a "virtual reality" with learning processes in a "natural reality".

There are challenges and chances of digitalization and A.I. for our future that cannot be predicted at the present moment. Therefore future teaching and teacher education should focus on building competences in a wide field: 
On the one hand it is crucial that we learn skills that belong to digitalization and that we keep control over the development of A.I., and on the other hand it is crucial that we keep a focus on our own development as human beings for the sake of ourselves and of future mankind. Means and contents that might contribute to these aims are for example the engagement with peace education, with environmental education, with education regarding media and with nonviolent communication.

\section{References}

Bayerischer Grundschullehrplan (2014). = https://www.lehrplanplus.bayern.de/schul art/grundschule.

Bohnenkamp, S. \& Luther, U. (2015). Projekt Naturwissenschaften - Brücken [Project Natural sciences - Bridges]. BVк Buch Verlag Kempen.

CNBC 1 (2017). https://www.cnbc.com/2017/12/18/g-mind-blowing-things-elon-musk -said-about-robots-and-ai-in-2017.html.

CNBC 2 (2017). https://www.cnbc.com/2017/07/17/elon-musk-robots-will-be-able-to -do-everything-better-than-us.html.

CNBC 3 (2017). https://www.cnbc.com/2017/11/o6/stephen-hawking-ai-could-be-worst -event-in-civilization.html.

CNBC 4 (2017). https://www.cnbc.com/2017/og/o4/elon-musk-says-global-race-for-ai -will-be-most-likely-cause-of-ww3.html.

Curran (2018). = https://www.theguardian.com/commentisfree $/ 2018 / \mathrm{mar} / 28 / \mathrm{all}-$ the -data-facebook-google-has-on-you-privacy.

DHV (2016). (Ed.). Forschung und Lehre [Research and Teaching]. 10/2016, 905.

Ebert, V. (2016). Unberechenbar [Unpredictable]. Reinbek bei Hamburg: Rowohlt.

Einsiedler, W. (2014). Grundlegende Bildung [Basic educution]. In Einsiedler, W., Götz, M., Hartinger, A., Heinzel, F., Kahlert, J. \& Sandfuchs, U. (Eds.): Handbuch Grundschulpädagogikund Grundschuldidaktik. Bad Heilbrunn: Klinkhardt, 225-233.

Gasse \& Dobbelstein (2008). https://www.iqesonline.net/download.cfm?id=d98ed 698-eoc6-b4e6-2991.

Götz (2005). http://www.bpb.de/gesellschaft/medien/kinder-sehen-krieg/64959/ chancen-fuer-bildung.

Gysi, G. (2018). Interview during the book presentation of his autobiography called "Ein Leben ist nicht genug" [One life is not enough] on nth of April 2018 in Erlangen, Germany, Bookstore Rupprecht.

Hüther (2015). https://www.focus.de/familie/schule/neurobiologe-gerald-huetherhirnforscher-was-man-lernen-will-muss-unter-die-haut-gehen_id_5073129.html.

Jäger (2016). http://www.bpb.de/internationales/weltweit/innerstaatliche-konflikte/ $54765 /$ bildungsarbeit-und-friedenserziehung. 
Jäger (2015). by-nc-nd/3.o/de/ Autor: Uli Jäger für bpb.de.

Klafki, W. (1985). Neue Studien zur Bildungstheorie und Didaktik. [New studies on the theory of education and didactics] Weinheim: Beltz.

MPFS (2016). https://www.mpfs.de/studien/kim-studie/2016.

Rosenberg (1). http://www.nonviolentcommunication.com/index.htm.

Rosenberg (2). http://www.cnvc.org/about/what-is-nvc.html.

Rosenberg. 3 = http://www.nonviolentcommunication.com/freeresources/article _archive/heartofnvc_mrosenberg.htm.

Rosenberg. 4 = https://www.nonviolentcommunication.com/freeresources/nvc_social _media_quotes.htm.

Rumi. http://www.cnvc.org/.

Scheunpflug, A. (2017). Globales Lernen - Geschichte [Global learning - History]. In:

Klemm, U. \& Lang-Wojtasik, G. (Eds.): Handlexikon Globales Lernen. Münster/Ulm: Klemm \& Oelschläger, 141-144.

Scheunpflug, A., Stadler-Altmann, U. \& Zeinz, H. (2012). Bestärken und fördern - Wege zu einer veränderten Kultur des Lernens in der Sekundarstufe i. Erarbeitet und erprobt im Modellversuch kompass - Kompetenz aus Stärke und Selbstbewusstsein [To encourage and to support - Ways to a new culture of learning in secundary schools. Developed and evaluated in the model project kompass - competence due to strength and self-confidence]. Seelze: Friedrich.

T-Online (2016). =http://www.t-online.de/nachrichten/deutschland/gesellschaft/id_79 779212/postfaktisch-was-das-wort-des-jahres-2016-bedeutet.html.

UNESCO (1945). = http://portal.unesco.org/en/ev.php-URL_ID=15244\&URL_DO=DO _TOPIC\&URL_SECTION=201.html.

UNICEF (2011). https://www.unicef.org/evaldatabase/index_61271.html.

Zeinz, H. (2009). Funktionen der Schule [functions of school]. In: Blömeke, S., Bohl, T., Haag, L., Lang-Wojtasik, G. \& Sacher, W. (Eds.). Handbuch Schule. Bad Heilbrunn: Klinkhardt, 87-94. 